\title{
Hypochlorous acid is a potent inhibitor of GST P1-1.
}

\author{
Citation for published version (APA):
}

van Haaften, R. I. M., den Hartog, G. J. M., Evelo, C. T. A., Haenen, G. R. M. M., \& Bast, A. (2001). Hypochlorous acid is a potent inhibitor of GST P1-1. Chemico-Biological Interactions, 138, 77-83. https://doi.org/10.1016/S0009-2797(01)00262-9

Document status and date:

Published: 01/01/2001

DOI:

10.1016/S0009-2797(01)00262-9

Document Version:

Publisher's PDF, also known as Version of record

Document license:
Taverne

\section{Please check the document version of this publication:}

- A submitted manuscript is the version of the article upon submission and before peer-review. There can be important differences between the submitted version and the official published version of record.

People interested in the research are advised to contact the author for the final version of the publication, or visit the DOI to the publisher's website.

- The final author version and the galley proof are versions of the publication after peer review.

- The final published version features the final layout of the paper including the volume, issue and page numbers.

Link to publication

\footnotetext{
General rights rights.

- You may freely distribute the URL identifying the publication in the public portal. please follow below link for the End User Agreement:

www.umlib.nl/taverne-license

Take down policy

If you believe that this document breaches copyright please contact us at:

repository@maastrichtuniversity.nl

providing details and we will investigate your claim.
}

Copyright and moral rights for the publications made accessible in the public portal are retained by the authors and/or other copyright owners and it is a condition of accessing publications that users recognise and abide by the legal requirements associated with these

- Users may download and print one copy of any publication from the public portal for the purpose of private study or research.

- You may not further distribute the material or use it for any profit-making activity or commercial gain

If the publication is distributed under the terms of Article $25 \mathrm{fa}$ of the Dutch Copyright Act, indicated by the "Taverne" license above, 


\title{
Hypochlorous acid is a potent inhibitor of GST P1-1
}

\author{
Rachel I.M. van Haaften *, Gertjan J.M. den Hartog, \\ Chris T.A. Evelo, Guido R.M.M Haenen, Aalt Bast
}

Department of Pharmacology and Toxicology, Faculty of Medicine, Universiteit Maastricht, PO Box 616, 6200 MD Maastricht, The Netherlands

Received 3 April 2001; received in revised form 28 June 2001; accepted 29 June 2001

\begin{abstract}
Glutathione S-transferase is a phase II detoxification enzyme that can be inactivated by $\mathrm{H}_{2} \mathrm{O}_{2}$. During oxidative stress various other reactive oxygen species are generated that are more reactive than the relatively stable $\mathrm{H}_{2} \mathrm{O}_{2}$. Hypochlorous acid $(\mathrm{HOCl})$ is a powerful oxidant which is highly reactive towards a range of biological substrates. We studied the influence of $\mathrm{HOCl}$ on the activity of GST P1-1. HOCl inhibits purified glutathione S-transferase $\mathrm{P} 1-1$ in a concentration dependent manner with an $\mathrm{IC}_{50}$-value of $0.6 \mu \mathrm{M}$, which is more than 1000 times as low as $\mathrm{IC}_{50}$ reported for $\mathrm{H}_{2} \mathrm{O}_{2}$. $\mathrm{HOCl}$ lowered the $V_{\max }$ value, but did not affect the $K_{\mathrm{m}}$ for CDNB. Our results show that $\mathrm{HOCl}$ is a potent, non-competitive inhibitor of GST P1-1. The relevance of this effect is discussed. (C) 2001 Elsevier Science Ireland Ltd. All rights reserved.
\end{abstract}

Keywords: Hypochlorous acid; Glutathione S-transferase P1-1; Inhibition; Human

\section{Introduction}

Glutathione S-transferases are a superfamily of phase II detoxification enzymes, which can catalyse the conjugation of glutathione with various electrophiles. The superfamily consists of at least five gene families of which four (alpha, mu, pi and theta) encode the cytosolic GSTs, whereas the fifth encodes a microsomal form of the enzyme [1-3]. In humans the pi-isoform of the enzyme occurs mostly in red

\footnotetext{
* Corresponding author. Tel.: + 31-43-388-1340; fax: + 31-43-388-4149.
}

E-mail address: r.vanhaaften@farmaco.unimaas.nl (R.I.M. van Haaften). 
blood cells and placenta [4] and has been shown to be especially vulnerable to oxidative stress $[5,6]$. It is known that GST P1-1 is inactivated in human erythrocytes by $\mathrm{H}_{2} \mathrm{O}_{2}$ [7].

The inhibition of GST by oxidative stress seems to be specific for GST P1-1. It is shown that GST P1-1 can be inactivated by $\mathrm{H}_{2} \mathrm{O}_{2}$, whereas GST $\mathrm{M}$ is not sensitive for inactivation with $\mathrm{H}_{2} \mathrm{O}_{2}$. In fact, GST $\mathrm{M}$ can even be activated by active oxygen species [8]. During oxidative stress various other reactive oxygen species are generated that are more reactive than the relatively stable $\mathrm{H}_{2} \mathrm{O}_{2}$. Hypochlorous acid $(\mathrm{HOCl})$ is a powerful oxidant generated by the neutrophil enzyme myeloperoxidase from $\mathrm{H}_{2} \mathrm{O}_{2}$ and chloride ions and it plays a role in the bactericidal function. It is highly reactive toward a range of biological substrates $[9,10]$. In the present study, the effect of $\mathrm{HOCl}$ on GST P1-1 activity is examined.

\section{Materials and methods}

\subsection{Chemicals}

1-Chloro-2,4-dinitrobenzene (CDNB), lipoic acid, sodium hypochlorous acid and glutathione S-transferase P1-1 (from human placenta) were obtained from Sigma, St. Louis, USA. Reduced glutathione (GSH) was obtained from ICN Biomedicals Inc., Costa Mesa, USA and hydrogen peroxide $\left(\mathrm{H}_{2} \mathrm{O}_{2}\right)$ from Merck, Darmstadt, Germany. All other chemicals were of analytical grade purity.

\subsection{Assay of glutathione $S$-transferase activity}

GST activity was measured as described by Mannervik and Guthenberg [11] with slight modifications. In short, the reaction of $1 \mathrm{mM} \mathrm{CDNB}$ with $1 \mathrm{mM} \mathrm{GSH}$ in the presence or absence of GST was monitored spectrophotometrically by recording the increase in absorbance at $340 \mathrm{~nm}$. Measurements were performed at $\mathrm{pH} 6.5$ to reduce the spontaneous reaction for the formation of the conjugate of GSH and CDNB.

\subsection{Incubations}

\subsubsection{Purified enzyme}

Effects of various concentrations of $\mathrm{HOCl}$ (final concentration $0.2-1 \mu \mathrm{M}$ ) on activity of purified GST P1-1 $(0.02 \mathrm{U} / \mathrm{ml})$ were determined. The GST enzyme was incubated in $100 \mathrm{mM}$ potassium phosphate $\mathrm{pH} 6.5$ or $7.4\left(37{ }^{\circ} \mathrm{C}\right)$ with or without lipoic acid. After preincubation (1 $\mathrm{min}), \mathrm{HOCl}$ was added and the reaction was allowed to proceed for $30 \mathrm{~s}$ before the activity of GST P1-1 was determined. The effect of $\mathrm{H}_{2} \mathrm{O}_{2}$ on the activity of purified GST P1-1 was determined in the same way.

To study the inhibitory mechanism of $\mathrm{HOCl}$ on GST P1-1, substrate concentrations (CDNB or GSH) were varied. When CDNB was varied, the GSH concentra- 
tion was kept at $1 \mathrm{mM}$ and vice versa. In these experiments the concentration of $\mathrm{HOCl}(0.75 \mu \mathrm{M})$ was constant.

\subsection{Lysate of human erythrocytes}

Effects of various concentrations $\mathrm{HOCl}$ (final concentration $0-75 \mu \mathrm{M}$ ) on GST activity in the lysate of human erythrocytes were also determined with the method described above. The lysate was prepared by mixing $1 \mathrm{ml}$ frozen blood from a male volunteer with $1 \mathrm{ml}$ cold water and $2 \mathrm{ml}$ cold $100 \mathrm{mM}$ potassium phosphate $\mathrm{pH} \mathrm{7.4.}$ This solution was mixed vigorously and centrifuged for $10 \mathrm{~min}$ at $13000 \mathrm{rpm}$ at $4{ }^{\circ} \mathrm{C}$. The supernatant was diluted 45 times. The incubation of the lysate with $\mathrm{HOCl}$ was performed at $\mathrm{pH} 7.4$, and the activity of GST was determined with GSH and $\mathrm{CDNB}$ as substrate after the $\mathrm{pH}$ was adjusted to $\mathrm{pH}$ 6.5.

Additionally, the reversibility of GST P1-1 inactivation by $\mathrm{HOCl}$ was studied. The GST was treated with $1 \mu \mathrm{M} \mathrm{HOCl}$ at $37{ }^{\circ} \mathrm{C}$ at $\mathrm{pH} 7.4$. After $30 \mathrm{~s}, 1 \mathrm{mM}$ GSH was added and the mixture was incubated again for $5 \mathrm{~min}$ at $37{ }^{\circ} \mathrm{C}$. Subsequently, the GST activity was measured. This activity was compared with the GST activity observed when GSH was added after the incubation of $5 \mathrm{~min}$, just before the addition of CDNB.

\section{Results}

As shown in Fig. 1, the glutathione S-transferase activity was inhibited by $\mathrm{HOCl}$ in a concentration dependent manner. The concentrations of $\mathrm{HOCl}$ giving $50 \%$ inhibition $\left(\mathrm{IC}_{50}\right)$ of GST P1-1 activity were $0.6 \mu \mathrm{M}$ for both pHs. $\mathrm{H}_{2} \mathrm{O}_{2}$ in a concentration of $1 \mathrm{mM}$ inhibited the GST P1-1 activity only $15 \%$. In the lysate of human erythrocytes $(\mathrm{pH} 7.4)$, the $\mathrm{IC}_{50}$ value of $\mathrm{HOCl}$ was $44 \pm 4 \mu \mathrm{M}$. A HOCl scavenger such as lipoic acid [12] can prevent the effect of $\mathrm{HOCl}$ on GST P1-1 (Fig.

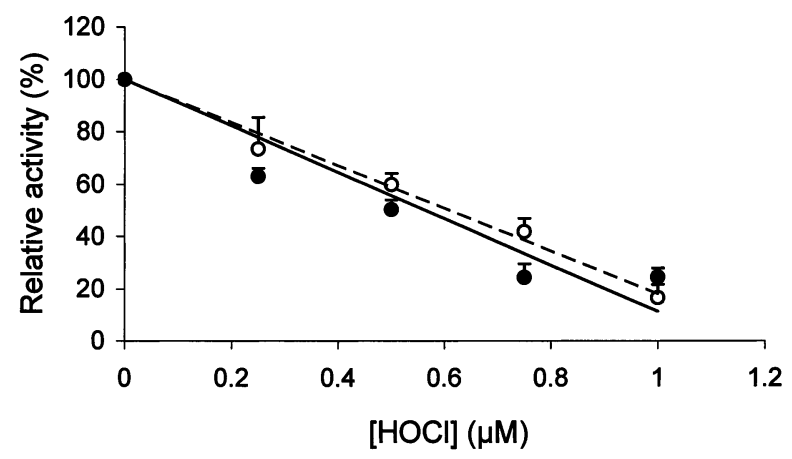

Fig. 1. Inactivation of isolated GST P1-1 by $\mathrm{HOCl}$. The inactivation was performed at $\mathrm{pH} 7.4$ (dashed line, - or $\mathrm{pH} 6.5$ (solid line, $\bigcirc$ ). The $\mathrm{IC}_{50}$ values of $\mathrm{HOCl}$ are $0.56 \mu \mathrm{M}$ and $0.61 \mu \mathrm{M}$ at $\mathrm{pH} 6.5$ and 7.4 , respectively. The concentration of the enzyme was $0.017 \mathrm{U} / \mathrm{ml}$. Each point denotes the means ( \pm S.E.M.) of three experiments. 


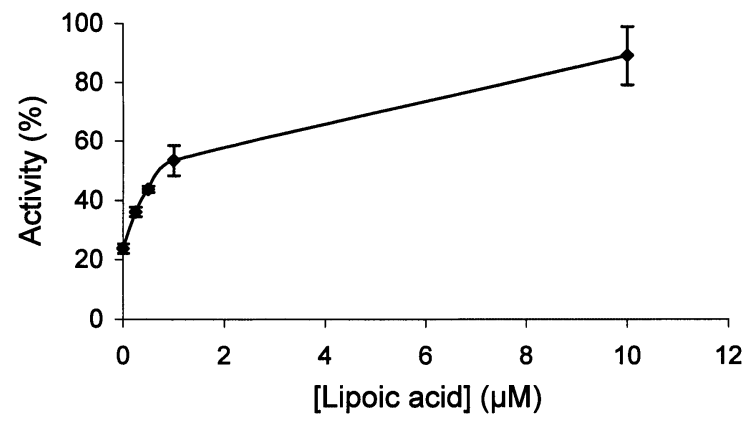

Fig. 2. Protection by lipoic acid against the inhibition of GST P1-1 by HOCl. The concentration of enzyme and $\mathrm{HOCl}$ were respectively $0.034 \mathrm{U} / \mathrm{ml}$ and $1.8 \mu \mathrm{M}$. Each point denotes the means $( \pm$ S.E.M.) of four measurements.

2). The inhibition of GST P1-1 by $\mathrm{HOCl}$ was not reversible by addition of GSH to the $\mathrm{HOCl}$ inactivated enzyme (data not shown).

To obtain information on the nature of the inhibition of GST P1-1 by $\mathrm{HOCl}$, GST activity of the purified enzyme with or without pre-treatment of $\mathrm{HOCl}(0.75$ $\mu \mathrm{M}$ ), was measured with variable concentrations of either CDNB or GSH. GST shows characteristic Michaelis Menten behaviour towards both substrates. The Lineweaver-Burk plot of the substrate CDNB is depicted in Fig. 3. As shown also in this figure, $\mathrm{HOCl}$ lowered the $V_{\max }$, but did not affect the $K_{\mathrm{m}}$ for either CDNB or GSH. This indicates that the GST P1-1 enzyme is non-competitively inhibited by $\mathrm{HOCl}$.

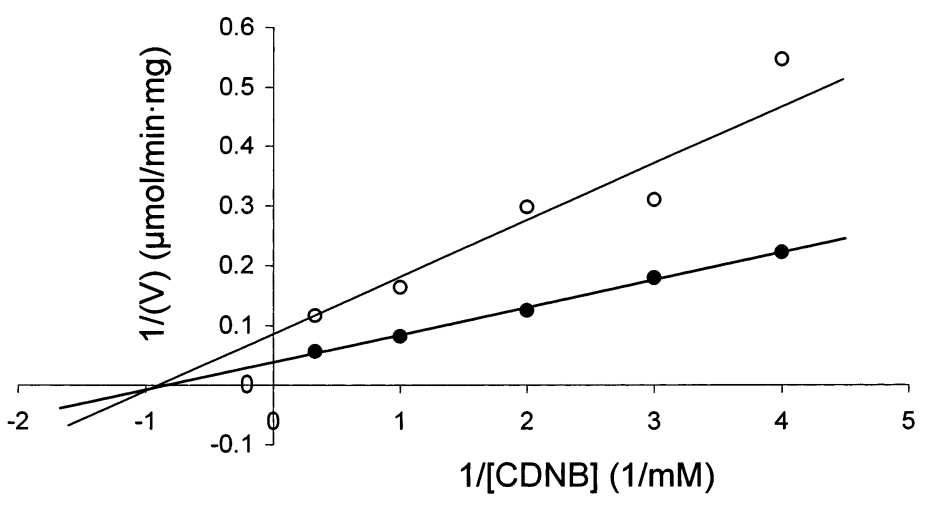

Fig. 3. Lineweaver-Burk plot showing non-competitive inhibition of human placenta GST P1-1 isoenzyme towards CDNB by $0.75 \mu \mathrm{M} \mathrm{HOCl}$. The $K_{\mathrm{m}}$ and $V_{\max }$ of the enzyme for CDNB (O) are respectively $1.2 \mathrm{mM}$ and $26 \mu \mathrm{mol} / \mathrm{min} \mathrm{mg}$. After $\mathrm{HOCl}$ treatment $(\bigcirc)$ these values are $1.1 \mathrm{mM}$ and 11 $\mu \mathrm{mol} / \mathrm{min} \mathrm{mg}$. The concentration enzyme used was $0.017 \mathrm{U} / \mathrm{ml}$. Each points denotes the means of four measurements. 


\section{Discussion}

GSTs can conjugate numerous electrophilic compounds, many of which are toxic, to GSH. In most cases, this conjugation leads to detoxification of the compounds [13]. The catalytic activity of the enzyme can be altered by different mechanisms. It is known that GST P1-1 can be inhibited by $\mathrm{H}_{2} \mathrm{O}_{2}$ [7].

This study confirmed the inhibition of GST P1-1 by $\mathrm{H}_{2} \mathrm{O}_{2}$. However, a relatively high concentration of $\mathrm{H}_{2} \mathrm{O}_{2}(1 \mathrm{mM})$ inhibited the enzyme $15 \%$. The potency of $\mathrm{HOCl}$ to inhibit the enzyme is much higher. When $\mathrm{HOCl}$ was added to a solution of isolated GST P1-1, the $\mathrm{IC}_{50}$-value was $0.6 \mu \mathrm{M}$ (Fig. 1). Higher potency of $\mathrm{HOCl}$ compared with $\mathrm{H}_{2} \mathrm{O}_{2}$ was also found for other important biological effects such as induction of apoptosis via caspase 3 [14]. For induction of apoptosis, the activity of $\mathrm{HOCl}$ exceeded even that of peroxynitrite [14].

It was shown that the inactivation of GST by $\mathrm{HOCl}$ is non-competitive and not reversible by $\mathrm{GSH}$. The $\mathrm{HOCl}$ scavenger lipoic acid can protect against the inactivation of GST by HOCl. Lipoic acid contains an intramolecular S-S bridge in a ring in which some strain exists. By scavenging $\mathrm{HOCl}$ the lipoic acid is converted into a sulphoxide [12].

Human GST contains 4 cysteine residues at positions 14, 47, 101 and 169. Disulphide formation between cysteine residues at positions 47 and 101 was found to be critical for the inactivation of GST P1-1. This results in steric hindrance which is the most probable cause for the inactivation [15]. It is known that $\mathrm{HOCl}$ also shows a high reactivity towards thiol groups $[12,16,17]$. Probably $\mathrm{HOCl}$ inhibits the GST P1-1 activity by oxidation of a cystein residue.

In erythrocytes GST P1-1 is the isoenzyme with the highest activity with respect to CDNB [18]. To inhibit the activity of GST in lysate of human erythrocytes, a much higher concentration of $\mathrm{HOCl}$ was needed compared with purified GST P1-1 ( $\mathrm{IC}_{50}$-values were 44 and $0.6 \mu \mathrm{M}$, respectively). The higher $\mathrm{IC}_{50}$ value in the lysate can be explained by the presence of GSH and thiol containing proteins that also can react with $\mathrm{HOCl}$.

One of the major targets of $\mathrm{HOCl}$ in vivo is $\alpha_{1}$-antiproteinase $\left(\alpha_{1}\right.$-AP). The $\mathrm{HOCl}$ mediated oxidation of this protein is an essential step in the etiology of lung emphysema [12]. A competition experiment, where $\alpha_{1}$-AP and GST P1-1 are mixed, revealed that $\mathrm{HOCl}$ first inactivates GST P1-1 before reacting with $\alpha_{1}$-AP (not published). This indicates that the inactivation of GST P1-1 by $\mathrm{HOCl}$ is of physiological relevance.

Besides the transferase activity of GST P1-1, another function has been reported recently. As a guardian of Jun N-terminal Kinase (JNK) in normally growing cells, GST P1-1 may serve as a sensor of intramolecular changes in redox potential that are elicited by various forms of stress [19]. Phosphorylation of Jun by JNK has been implicated in changes in the cell cycle, DNA repair or apoptosis [18]. It is tempting to speculate that $\mathrm{HOCl}$ is one of the important triggers in this system since $\mathrm{HOCl}$ is a much more potent inhibitor of GST P1-1 than the other stressors (i.e. $\mathrm{H}_{2} \mathrm{O}_{2}$ ) studied thus far. Together with the proclaimed role of $\mathrm{HOCl}$ in activation of caspase 3 [14], elevation of p53 levels [20], induction of the expression 
of apurinic endonuclease [21] and the activation of $\mathrm{NF}-\kappa \mathrm{B}$ [22], this points toward a pivotal function of $\mathrm{HOCl}$ in (patho-)physiology.

\section{Acknowledgements}

We are grateful to Marjolein Hemelt and Karlien v. d. Hout for their help with the experiments.

\section{References}

[1] B. Mannervik, The isoenzymes of glutathione transferase, Adv. Enzymol. RAMB 57 (1985) $357-417$.

[2] J.D. Hayes, D.J. Pulford, The glutathione S-transferase supergene family: regulation of GST and the contribution of the isoenzymes to cancer chemoprotection and drug resistance, Crit. Rev. Biochem. Mol. Biol. 30 (1995) 445-600.

[3] K. Uchida, Induction of glutathione S-transferase, Mech. Ageing Dev. 116 (2000) 135-140.

[4] C. Guthenberg, B. Mannervik, Glutathione S-transferase (transferase $\pi$ ) from human placenta is identical or closely related to glutathione S-transferase (transferase p) from erythrocytes, Biochim. Biophys. Acta 661 (1981) 255-260.

[5] V.M. Neefjes, C.T.A. Evelo, L.G.M. Baars, C.E. Blanco, Erythrocyte glutathione S transferase as a marker of oxidative stress at birth, Arch. Dis. Child Fetal Neonatal Ed. 81 (1999) F130-F133.

[6] A.A.M.G. Spooren, C.T.A. Evelo, Only the glutathione dependent antioxidant enzymes are inhibited by haematotoxic hydroxylamines, Hum. Exp. Toxicol. 17 (1998) 554-559.

[7] H.X. Shen, K. Tamai, K. Satoh, I. Hatayama, S. Tsuchida, K. Sato, Modulation of class Pi glutathione transferase activity by sulfhydryl group modification, Arch. Biochem. Biophys. 286 (1991) $178-182$.

[8] T. Murata, I. Hatayama, K. Satoh, S. Tsuchida, K. Sato, Activation of rat glutathione transferases in class mu by active oxygen species, Biochem. Biophys. Res. Commun. 171 (1990) 845-851.

[9] M.B. Hampton, A.J. Kettle, C.C. Winterbourn, Inside the neutrophil phagosome: oxidants, myeloperoxidase, and bacterial killing, Blood 92 (1998) 3007-3017.

[10] J.M. Pullar, C.C. Winterbourn, M.C. Vissers, Loss of GSH and thiol enzymes in endothelial cells exposed to sublethal concentrations of hypochlorous acid, Am. J. Physiol. 277 (1999) H1505H1512.

[11] B. Mannervik, C. Guthenberg, Glutathione transferase (Human placenta), Method Enzymol. 77 (1981) 231-235.

[12] G.R.M.M. Haenen, A. Bast, Scavenging of hypochlorous acid by lipoic acid, Biochem. Pharmacol. 42 (1991) 2244-2246.

[13] D.L. Eaton, T.K. Bammler, Concise review of the glutathione S-transferases and their significance to toxicology, Toxicol. Sci. 49 (1999) 156-164.

[14] M.C.M. Vissers, J.M. Pullar, M.B. Hampton, Hypochlorous acid causes caspase activation and apoptosis or growth arrest in human endothelial cells, Biochem. J. 344 (1999) 443-449.

[15] B. Mannervik, U.H. Danielson, Glutathione transferases-Structure and catalytic activity, CRC Crit. Rev. Biochem. 23 (1988) 283-337.

[16] C.C. Winterbourn, Comparative reactivities of various biological compounds with myeloperoxidase-hydrogen peroxide-chloride, and similarity of the oxidant to hypochlorite, Biochim. Biophys. Acta 840 (1985) 204-210.

[17] A.C. Carr, C.C. Winterbourn, Oxidation of neutrophil glutathione and protein thiols by myeloperoxidase-derived hypochlorous acid, Biochem. J. 327 (1997) 275-281. 
[18] A. Fazi, A. Accorsi, E. Piatti, M. Magnani, Cell age dependent decay of human erythrocytes glutathione S-transferase, Mech. Ageing Dev. 58 (1991) 255-266.

[19] V. Adler, Z. Yin, S.Y. Fuchs, M. Benezra, L. Rosario, K.D. Tew, M.R. Pincus, M. Sardana, C.J. Henderson, C.R. Wolf, R.J. Davis, Z. Ronai, Regulation of JNK signaling by GSTp, EMBO J. 18 (1999) $1321-1334$.

[20] G.F. Vile, L.A. Rothwell, A.J. Kettle, Hypochlorous acid acitivates the tumor suppressor protein p53 in cultured human skin fibroblasts, Arch. Biochem. Biophys. 359 (1998) 51-56.

[21] S. Grosch, G. Fritz, B. Kaina, Apurinic endonuclease (Ref-1) is induced in mammalian cells by oxidative stress and involved in clastogenic adaptation, Cancer Res. 58 (1998) 4410-4416.

[22] S. Schoonbroodt, S. Legrand-Poels, M. Best-Belpomme, J. Piette, Activation of the NF- $\mathrm{B}$ transcription factor in a T-lymphocytic cell line by hypochlorous acid, Biochem. J. 321 (1997) 777-785. 